\title{
Response of Cucurbitaceae seedlings, Cucurbita mochata, Cucurbita pepo and Lagenaria siceraria to the fertilization by pig dejecta at Brazzaville, Congo
}

\author{
ISSALI Auguste Emmanuel ${ }^{1 *}$, MPIKA Joseph², MOKOLO Jean Baptiste ${ }^{2}$, ATTIBAYEBA ${ }^{2}$ \\ 1 Faculty of Sciences and Techniques, PO Box 69, Marien NGOUABI University, Congo -Brazzaville; Email: \\ jeanbaptistmokolo@gmail.com ; Cel: 002420690833 11, mpika@yahoo.fr ; Cel: 002420652742 46, \\ pattibayeba@gmail.com ; Cel: 00242066298237 \\ $2^{\star}$ National Higher School of Agronomy and Forestry, Marien NGOUABI University, Congo-Brazzaville, Phone: 00242 \\ 0684406 23, Email: issaliemma@yahoo.com
}

Original submitted in on 10th February 2020. Published online at www.m.elewa.org/journals/ on $30^{\text {th }}$ June 2020 https://doi.org/10.35759/JABs.150.7

\begin{abstract}
Objective: To assess the main effects of three "Species" of Cucurbitaceae and two "Status" of their seedlings, individually taken, their interactions related to three variables measured on stem, three variables measured on leaf and one variable measured on flower were tested.

Methodology and Results: Cucurbita moschata, Cucurbita pepo and Lagenaria Siceraria were used as genotypes. They were planted according to a completely randomised design. Growth variables were measured on the stem, leaf and flower. The General Linear Model combining the comparison of means according to the Student NewmanKeuls test as well as the Student t or Z test with two samples at the risk threshold of $5 \%$ were applied. With regard to the first of the 3 interactions, the variations of the diameter at the collar (DC), diameter of the rod (DT) and length of the rod (LT) were independent of the variations of "Species" and "Status "authorizing the classifications of the variants of the aforementioned factors. For the second of the 3 interactions, the fluctuations in leaf length (LF), blade width (IL) and blade length (LL2) were dependent of the simultaneous fluctuations of the species and the Prohibiting Status any classification. Regarding the third interaction, the variations in the number of flowers produced (NFP) were independent of those concomitant with the Species and Status, allowing classification of the same variants of the above factors. For the first of the 3 interactions mentioned above, concerning the main effects "Species" and "Status", Lagenaria siceraria recorded both the highest diameter at the collar and the longest stem as well as a greater growth of seedlings treated with pig dejecta. . This suggests that growth in Cucurbitaceae is genotype dependent. It is also influenced by pig dejecta. Concerning the same main effects "Species" and "Status", linked to the third interaction, Cucurbita pepo and the seedlings treated with organic dejecta from pigs expressed the greatest cumulative effective number of flowers (EFFCUM).

Conclusion and application of the results: Factors "Species" and "Status" can be studied simultaneously, because they do not interact on the DC, DT, LT and EFFCUM. Lagenaria siceraria grows very well relative to the first 3 variables mentioned above while Cucurbita pepo expresses a high cumulative number of flowers. Three kilograms of pig dejecta are necessary to allow good growth of the stem and diameter of Largenaria siceraria. The latter should be used for the production of aboveground biomass while Cucurbita pepo should be used for the production of fruits.
\end{abstract}

Key words: Growth variables, GLM of Anova, pig dejecta, interaction. 


\section{RESUME}

Objectif : Pour évaluer les effets principaux, de trois "Espèces" et deux "Statuts" des plants de semis, pris individuellement, leurs interactions liées à trois variables mesurées sur la tige, trois variables mesurées sur la feuille et une variable mesurée sur la fleur ont été testées.

Méthodologie et Résultats : Cucurbita moschata, Cucurbita pepo et Lagenaria Siceraria ont été utilisés comme génotypes. Ils ont été plantés selon un dispositif en bloc complètement aléatoire. Des variables de croissance ont été mesurées sur la tige, la feuille et la fleur. Le Modèle Géneral Linéaire associant la comparaison de moyennes selon le test de Student Newman-Keuls ainsi que le test t ou $Z$ de Student à deux échantillons au seuil de risque de $5 \%$ ont été appliqués. En ce qui concerne la première des 3 interactions, les variations du diamètre au collet (DC), diamètre de la tige (DT) et longueur de la tige (LT) ont été indépendantes des variations de "l'Espèce" et du "Status" autorisant les classifications des variantes de facteurs pré-cités. Pour la deuxième des 3 interactions, les fluctuations de la longueur de la feuille (LF), de la largeur du limbe (IL) et de la longueur du limbe (LL2) ont été dépendantes des fluctuations simultanées de l'Espèce et du Statut, interdisant toute classification. Concernant, la troisième interaction, les variations du nombre de fleurs produites (NFP) ont été indépendantes de celles concomitantes de l'Espèce et du Status, permettant la classification des mêmes variantes de facteurs sus-cités. Pour la première des 3 interactions sus-mentionnées, concernant les effets principaux "Species" et "Status", Lagenaria siceraria a enregistré à la fois le plus haut diamètre au collet et la tige la plus longue ainsi qu'une plus grande croissance de plants de semis traités avec la fumure de porc. Ceci suggère que la croissance chez les Cucurbitaceae est genotype dépendant. Elle est aussi influencée par la fumure de porc. Concernant les mêmes effets principaux "Species" et "Status", liés à la $3^{\mathrm{e}}$ interaction, Cucurbita pepo et les plants de semis traités avec la fumure organique de porc ont exprimé le plus grand nombre effectif cumulé de fleurs (EFFCUM).

Conclusion et application des résultats : Facteurs "Species" et "Status" peuvent être simultanément étudiés, car ils n'interagissent pas sur le DC, DT, LT ainsi que l'EFFCUM. Lagenaria siceraria croit très bien relativement aux 3 premières variables sus-citées alors que Cucurbita pepo exprime un haut effectif cumulé de fleurs. Trois Kilogrammes de fumure de porc sont nécessaires pour permettre une bonne croissance de la tige et du diamètre de Largenaria siceraria. Ce dernier devrait être utilisé pour la production de la biomasse aérienne alors que Cucurbita pepo devrait l'être pour la production de fruits.

\section{INTRODUCTION}

Cucurbitaceae is family of dicotyledonous plants used in the human food. They are used as food, source of proteins and fats yielding as well as secondary metabolites (Toshihiro et al., 2001). World squash yielding reaches 16 million tonnes obtained from 1.3 million hectares (Robinson, 1997). In Congo (Brazzaville), the Pool, Bouenza and Plateaux regions yield squash (Dupriez et al., 1987). The species of Cucurbitaceae such as Cucurbita mochata, Cucurbita pepo and Lagenaria siceraria are cultivated for food and medicinal purposes. Nonetheless, no statistics is available. Likewise, no information is available about the agro-morphological description of local Congolese cultivars. Nevertheless, ethno-botanical and biochemical studies were carried out (Moutsamboté et al., 1988; Mampouya et al., 2012). Thus, the characteristics related to the growth of stem, leaf and flowers are unknown. Indeed, on-station and on-farm trials evidencing the characteristics of stem, leaf and flowers have never been achieved in Congo-
Brazzaville. Likewise, no information is available about interaction between two factors implied in an onstation and on-farm studies. The achieving of these trials in the field could allow good description of locally cultivated species. Likewise, factors such as "Species" accounting for genotypes and "Status" of seedlings corresponding to the adding or not of the organic pig dejecta were never tested in the form of interaction and main effects. The test of effects of these factors might allow us to know whether we can study them simultaneously. For that, we postulate that the variations of diameter at collar, diameter of stem and length of stem as well as cumulative count of flowers are independent of those from factors "Species" and "Status" of seedlings. The work aimed to study the response to the fertilisation by pig's dejecta of the Cucurbitaceae seedlings of Cucurbita mochata, Cucurbita pepo and Lagenaria siceraria at Brazzaville, Congo 
Issali et al., J. Appl. Biosci. 2020 Response to the growth of the Cucurbitaceae seedlings of Cucurbita mochata, Cucurbita pepo and Lagenaria siceraria fertilised or not with organic pig manure at Brazzaville, Congo

\section{MATERIALS AND METHODS}

Study site, plant material, soil state, trial monitoring, installing and experimental design: Experiment was installed and monitored at the garden of Faculty of Sciences and Techniques from Marien Ngouabi University. This one is located at Bacongo area, particularly at $15^{\circ} 15^{\prime} 17.3^{\prime \prime}$ West longitude, $4^{\circ} 17^{\prime} 1.7^{\prime \prime}$ North latitude and 291 metres above sea level. This experiment was carried out from 3nd January to 30th May 2018. Climate is sub-equatorial type with small dry and minor rainy seasons as well as long rainy and long dry seasons. Structure of soil is particulate type with clay sand texture. Plant material consisted of three species, known as Cucurbita moschata, Cucurbita pepo and Lagenaria siceraria whose seeds were used in experiment. Experiment area measuring $120 \mathrm{~m}^{2}$ brought six ridges of 11 metres in length and 1.20 metre width each. Each ridge brought two rows of plantation of 10 seedlings each. Gap of 1 metre was maintained among seedlings from the same row. Organic pig dejecta used as basal fertilisation was added in seed pocket due to 3 seeds per pocket. Three ridges received organic fertilisation while three others did not receive it. A twocomplete factor $3 \times 2$ scheme in a completely randomised design was used. Factors "Species" and "Status" with 3 and 2 variants respectively were tested. Here, treatment was defined as a combination of variants of factors "Species" and "Status" of seedlings. Six treatments were tested. Each treatment being in triplicate, in all 18 treatments were installed in the experimental design. Density of plantation was 1.51

\section{RESULTS}

Impact of the three tested species and dejecta addition, on the expression of the DC, DT and LT: The examination of interaction Species $x$ Status revealed that the variations of diameter at collar (DC), diameter of stem (DT) and that of length of stem (LT) were independent of concomitant variations of Species and Status ( $p$-values $D C=0.296$; $p$-values $D L=0.358$; $p$-values $L T=0.444)$.. This examination shows that seedling $/ \mathrm{m}^{2}$. Two weeks after the sowing, germinated seeds and having been regenerated in seedlings were separate. The surplus was conserved onto ridge for potential replacement. Seedlings were watered with 50 litres of water per ridge. Weeding and harrowing were done lightly every two weeks. Measurements were carried out one month later. Two groups of variables were measured. These are growth and flowering variables. The former were composed of stem and leaf variables whereas the latter consisted of cumulative flowers count (EFFCUM). Variables of stem were accounted for by diameter at collar (DC), diameter of stem (DT) and length of stem (LT). Variables of leaf were constituted of length of leaf (LF), width of blade (IL) and length of blade (LL2). Variable of flowering consisted of cumulative count of flowers yielded (EFFCUM)

Statistical data analysis: XIstat and SPSS software, versions 2007 and 22.0, respectively were used. Means comparison incorporated in Anova with or without GLM as well as Student's parametric two-sample t or Z test at $5 \%$ likelihood were applied. For Anova, the following model, related to completely randomised design was applied: $Y=\mu+$ Species + Status + Species $\times$ Status $+\varepsilon$. Where, $Y$ is response variable. $\mu$ is general mean. Species is the first factor comprising three variants. Status is the second one counting two variants. Species $x$ Status represents the interaction between the two above factors cited. $\varepsilon$ is the error. Error eij is supposed to be normally distributed with null mean and variance $\sigma^{2}$, that is to say, eij $\sim \mathrm{N}\left(0, \sigma^{2}\right)$.

when passed from Species to Species or from Status to Status, such variations trigger the significant variations of diameter at collar ( $\mathrm{p}$-values $\left.\mathrm{DC}=0.000^{\star * *}\right)$ and those of length of stem ( $p$-values $L T=0.000^{\star * *}$ ). These variations can be structured in distinct sub-sets. In the same way, regarding the Status of seedlings. This allowed classifying the means of factors "Species" and "Status" (Table1). 
Issali et al., J. Appl. Biosci. 2020 Response to the growth of the Cucurbitaceae seedlings of Cucurbita mochata, Cucurbita pepo and Lagenaria siceraria fertilised or not with organic pig manure at Brazzaville, Congo

Table 1: Assessment of the effects of factors "Species" and "Status" of seedlings on the expression of three measured variables through Anova.

\begin{tabular}{|c|c|c|c|c|c|c|}
\hline Source & Dependent variable* & SS $^{*}$ & $d f^{*}$ & MS* & $F^{*}$ & p-value* \\
\hline \multirow[t]{3}{*}{ Corrected model } & DC & 6.034 & 5 & 1.207 & 28.707 & 0.000 \\
\hline & DT & 100.759 & 5 & 20.152 & 1.3 & 0.262 \\
\hline & LT & $2164614.520 c$ & 5 & 432922.904 & 12.05 & 0.000 \\
\hline \multirow[t]{3}{*}{ Intercept } & DC & 199.497 & 1 & 199.497 & 4745.31 & 0.000 \\
\hline & DT & 341.675 & 1 & 341.675 & 22.1 & 0.000 \\
\hline & LT & 14348907 & 1 & 14348907 & 399.29 & 0.000 \\
\hline \multirow[t]{3}{*}{ Species } & DC & 5.133 & 2 & 2.566 & 61.05 & 0.000 \\
\hline & DT & 44.279 & 2 & 22.14 & 1.432 & 0.241 \\
\hline & LT & 1605897.54 & 2 & 802948.77 & 22.344 & 0.000 \\
\hline \multirow[t]{3}{*}{ Status } & $\mathrm{DC}$ & 0.799 & 1 & 0.799 & 18.997 & 0.000 \\
\hline & DT & 24.573 & 1 & 24.573 & 1.589 & 0.208 \\
\hline & LT & 500208.333 & 1 & 500208.333 & 13.919 & 0.000 \\
\hline \multirow[t]{3}{*}{ Species $\times$ Status } & $D C$ & 0.103 & 2 & 0.051 & 1.224 & 0.296 \\
\hline & DT & 31.907 & 2 & 15.953 & 1.032 & 0.358 \\
\hline & LT & 58508.647 & 2 & 29254.323 & 0.814 & 0.444 \\
\hline \multirow[t]{3}{*}{ Error } & $D C$ & 12.36 & 294 & 0.042 & & \\
\hline & DT & 4545.891 & 294 & 15.462 & & \\
\hline & LT & 10565330.5 & 294 & 35936.498 & & \\
\hline \multirow[t]{3}{*}{ Total } & $D C$ & 217.892 & 300 & & & \\
\hline & DT & 4988.325 & 300 & & & \\
\hline & LT & 27078852 & 300 & & & \\
\hline \multirow[t]{3}{*}{ Corrected total } & $D C$ & 18.394 & 299 & & & \\
\hline & DT & 4646.65 & 299 & & & \\
\hline & LT & 12729945 & 299 & & & \\
\hline
\end{tabular}

Legend. Dependent variable*: DC: Diameter at collar. DT: Diameter of stem. LT: Length of stem. SS*: Sum of squares. df*: Degree of freedom. MS*: Mean of square. F*: Fisher-Snedecor's test statistics. P-value*: Critical value.

Regarding factor "Species", three classes were both identified for diameter at collar and length of stem as against one for diameter of stem. Firstly, consisting of Species Cucurbita moschata was distinguished by small diameter at collar and length of stem. Secondly, constituted of Species Cucurbita pepo L. was marked by average diameter at collar and length of stem. Thirdly, composed of Species Lagenaria siceraria, was characterised by big diameter at collar and high length of stem (Table 2). With respect to "Status", here also, out of diameter of stem, two distinct sub-sets were revealed with respect to diameter at collar and length of stem. In the first, composed of seedlings at which no organic pig dejecta as basal fertilisation was added, was characterised by low diameter at collar and length of stem. In the second, consisted of seedlings for which organic pig fertiliser as basal fertilisation was brought, was singular in high diameter at collar and length of stem (Table 2). 
Issali et al., J. Appl. Biosci. 2020 Response to the growth of the Cucurbitaceae seedlings of Cucurbita mochata, Cucurbita pepo and Lagenaria siceraria fertilised or not with organic pig manure at Brazzaville, Congo

Table 2: Means classification of the diameter at collar, diameter of stem and length of stem as a function of the species and dejecta adding.

\begin{tabular}{|c|c|c|c|c|c|c|c|}
\hline Dependent variable* & Status* & Mean* & CV $(\%)^{*}$ & Dependent variable & Species* & Mean & CV (\%) \\
\hline \multirow[t]{2}{*}{ DC } & Without dejecta & $0.764 a$ & 2.56 & \multirow[t]{3}{*}{$\mathrm{DC}$} & $\mathrm{Cm}$ & $0.636 a$ & 3.30 \\
\hline & With dejecta & $0.867 \mathrm{~b}$ & 2.32 & & Cp & $0.653 b$ & 6.18 \\
\hline \multirow[t]{2}{*}{ DT } & Without dejecta & $0.781 \mathrm{a}$ & 2.33 & & Ls & $0.868 c$ & 2.42 \\
\hline & With dejecta & $1.353 a$ & 3.57 & \multirow[t]{3}{*}{ DT } & $\mathrm{Cm}$ & $0.943 a$ & 2.23 \\
\hline \multirow[t]{5}{*}{ LT } & Without dejecta & $177.867 a$ & 7.45 & & Cp & $0.970 a$ & 4.52 \\
\hline & With dejecta & $259.533 b$ & 7.43 & & Ls & $1.579 a$ & 24.89 \\
\hline & & & & \multirow[t]{3}{*}{ LT } & $\mathrm{Cm}$ & $136.260 \mathrm{a}$ & 13.91 \\
\hline & & & & & Cp & $205.770 \mathrm{~b}$ & 9.21 \\
\hline & & & & & Ls & $314.070 c$ & 6.04 \\
\hline
\end{tabular}

Legend. Dependent variable*: DC: Diameter at collar. DT: Diameter of stem. LT: Length of stem. Treatment*: Without dejecta: Control treatment. With dejecta: Tested treatment. Mean*: Values accompanied by the same letter are not significantly different according to Student's parametric two-sample Z test at $5 \%$ level. CV (\%)*: Coefficient of variation. Species*: Cm: Cucurbita moschata. Cp: Cucurbita pepo. Ls: Lagenaria Siceraria.

Influence of the factors "Species" and "Status" of seedlings on the expression of three measured variables on leaves: The appreciating of interaction Species $x$ Status of seedlings shown that the variations of length of leaf (LF), width of blade (IL) and length of blade (LL2) were dependent of simultaneous variations of Species and Status ( $p$-value LF $=0.004^{* *} ; p$-value IL= $0.000^{* * *} ; p$-value LL2 $\left.=0.000^{* * *}\right)$. This suggested the non-examination of main effects (Table 3 ).

Table 3: Assessment of the effects of factors "species" and "treatment" on the expression of length of leaf, width of blade and length of blade via Anova.

\begin{tabular}{|c|c|c|c|c|c|c|}
\hline Source & Dependent variable* & SS & df & MS & $F$ & $p$-value \\
\hline \multirow[t]{3}{*}{ Corrected model } & LF & 50260.475 & 5 & 10052.095 & 256.564 & 0.000 \\
\hline & IL & 20259.746 & 5 & 4051.949 & 249.426 & 0.000 \\
\hline & LL2 & 4780.605 & 5 & 956.121 & 59.033 & 0.000 \\
\hline \multirow[t]{3}{*}{ Intercept } & LF & 652737.857 & 1 & 652737.857 & 16660.127 & 0.000 \\
\hline & IL & 345617.475 & 1 & 345617.475 & 21275.193 & 0.000 \\
\hline & LL2 & 188210.975 & 1 & 188210.975 & 11620.508 & 0.000 \\
\hline \multirow[t]{3}{*}{ Species } & LF & 49397.873 & 2 & 24698.936 & 630.402 & 0.000 \\
\hline & IL & 18786.351 & 2 & 9393.175 & 578.216 & 0.000 \\
\hline & LL2 & 2531.772 & 2 & 1265.886 & 78.158 & 0.000 \\
\hline \multirow[t]{3}{*}{ Status } & LF & 425.221 & 1 & 425.221 & 10.853 & 0.001 \\
\hline & IL & 930.273 & 1 & 930.273 & 57.265 & 0.000 \\
\hline & LL2 & 314.263 & 1 & 314.263 & 19.403 & 0.000 \\
\hline \multirow[t]{3}{*}{ Species $\times$ Status } & LF & 431.019 & 2 & 215.510 & 5.501 & 0.004 \\
\hline & $\mathrm{IL}$ & 567.073 & 2 & 283.537 & 17.454 & 0.000 \\
\hline & LL2 & 1896.972 & 2 & 948.486 & 58.561 & 0.000 \\
\hline \multirow[t]{3}{*}{ Error } & LF & 58416.850 & 1491 & 39.180 & & \\
\hline & IL & 24221.432 & 1491 & 16.245 & & \\
\hline & LL2 & 24148.907 & 1491 & 16.196 & & \\
\hline \multirow{3}{*}{ Total } & LF & 771444.060 & 1497 & & & \\
\hline & IL & 394956.750 & 1497 & & & \\
\hline & LL2 & 218590.500 & 1497 & & & \\
\hline \multirow[t]{3}{*}{ Corrected total } & LF & 108677.325 & 1496 & & & \\
\hline & $\mathrm{IL}$ & 44481.179 & 1496 & & & \\
\hline & LL2 & 28929.511 & 1496 & & & \\
\hline
\end{tabular}

Legend. Dependent variable*: LF: length of leaf. IL: width of blade. LL2: length of blade. 
Effect of the factors "Species" and "Status" on the expression of the cumulative count of flowers: The analysis of interaction Species $x$ Status of seedlings shown that the variations of cumulative count of flowers independent of concurrent variations of Species and Status. This allowed the appreciating of main effects "Species" and "Status". Indeed, the variations of Species caused the variations of cumulative count of flowers suggesting the possibility to classify these Species in distinct classes. In the same way, the variations of Status of seedlings triggered the variations of cumulative count of flowers. These variations can be structured in distinct groups (Table 4). This authorised the means classification of cumulative count of flowers.

Table 4: Assessment of the effects of factors "Species" and "Status" of seedlings on the expression of the cumulative count of flowers by means of Anova.

\begin{tabular}{c|c|c|c|c|c}
\hline Source & SS & df & MS & F & p-value \\
\hline Corrected model & 407024.377 & 5 & 81404.875 & 37.448 & 0.000 \\
Intercept & 1016986.96 & 1 & 1016986.96 & 467.838 & 0.000 \\
Species & 386757.547 & 2 & 193378.773 & 88.959 & 0.000 \\
Status & 16295.07 & 1 & 16295.07 & 7.496 & 0.007 \\
Species x Status & 3971.76 & 2 & 1985.88 & 0.914 & 0.402 \\
Error & 639097.66 & 294 & 2173.802 & & \\
Total & 2063109 & 300 & & & \\
Corrected total & 1046122.04 & 299 & & & \\
\hline
\end{tabular}

As far as the factor "Species" is concerned, three subsets were observed. First, accounted for by Species Cucurbita moschata was characterised by low cumulative count of flowers. Second, composed of Species Lagenaria siceraria was marked by average cumulative count of flowers. Third, constituted of Species Cucurbita pepo was singular in high cumulative count of flowers. Coefficient of variation varied from 4.9 to $19.12 \%$ (Table 5). As for "Status" of seedlings, two distinct groups were displayed. Firstly, constituted of seedlings at which no organic pig fertiliser as basal fertilisation was added, was marked by low cumulative count of flowers. Secondly, consisting of seedlings at which organic pig fertiliser as basal fertilisation was added was distinguished by high cumulative count of flowers. Magnitude of variation between the mean and each of modalities of the cumulative flowers count fluctuated from 5.8 to $7.49 \%$ (Table 5 ).

Table 5: Means classification of the cumulative count of flowers as a function of the species and status.

\begin{tabular}{c|c|c|c|c}
\hline Dependent variable & Factor & Treatment & Mean $^{*}$ & CV (\%) \\
\hline EFFCUM & Status & Without dejecta & $50.853 \mathrm{a}$ & 7.49 \\
& & With dejecta & $65.593 \mathrm{~b}$ & 5.8 \\
\cline { 2 - 5 } & Species & Cm & $16.01 \mathrm{a}$ & 19.12 \\
& & Ls & $54.89 \mathrm{~b}$ & 8.49 \\
& & Cp & $103.77 \mathrm{c}$ & 4.49 \\
\hline
\end{tabular}

Legend. Dependent variable*. EFFCUM: Cumulative count of flowers. Treatment. Cm: Cucurbita moschata. Ls: Largenaria siceraria. Cp: Cucurbita pepo L. Mean*: Values accompanied by different letters in column are significantly different according to Student's parametric two-sample Z and Student-Newman-Keuls' tests at 5\% probability.

\section{DISCUSSION}

Reciprocal influence Species $x$ Status of seedlings was analysed with a view to appreciate their main effects, respectively, on the expression of seven measured variables. Works from Bertucci et al., (2018) revealed the lacking of interaction among rootstock, species and harvest date in cucurbits. Density $x$ Season interaction tested in Dje-Bi et al., (2011) working onto Cucurbitaceae did not display the existence of interaction. Our works showed the non-existence of interaction with variables from stem and leaf but its existence with variables from the growth of leaf. Reciprocal effect Species x Status of seedling was nonexistent with diameter at collar, diameter of stem and length of stem as well as length of leaf, width of blade and length of blade. However, this interaction was significant with cumulative count of flowers. The lacking of interaction might be found an explanation through the absence of competition for nutrients for the same cell 
sites brought by organic pig dejecta for stem and leaf developments. This might be due to action of these nutrients on distinct genes activity on DNA. In opposite, the existence might find an explanation through the competition for nutrients for the same cell sites brought by organic pig dejecta for stem and leaf developments. In the same way, this interaction existence might be due to action of these nutrients on the genes activity brought by DNA. In sum, the lacking or existence of interaction Species $x$ Status of seedlings might be due to action of nutrients on distinct or similar cell sites or action of these nutrients on distinct or identical genes from DNA. Works from Bertucci et al., (2018) revealed the lacking of interaction among rootstock, species and harvest date in cucurbits. In contrast, Issali et al., (2011) shown the existence of interaction between Staminodes $x$ Petals in co-culture relatively to number of yielded callus. Consequently, in future, it will be necessary to continue measurements on stem and leaves when the 3 species of Cucurbitaceae when submitted to adding of organic pig dejecta. Likewise, it will be necessary to avoid measurement of cumulative count of flowers when the 3 species and 2 Status will be associated.

\section{CONCLUSION}

This study postulated that the variations of diameter at collar, diameter of stem and length of stem as well as cumulative count of flowers are independent of those from factors "Species" and "Status" of seedlings. Effectively, interaction was not significant relatively to diameter at collar and length of stem as well as cumulative count of flowers. Consequently, variants of factors whose interaction was not significant were classified. In future, it will be necessary to continue measurements on stem and leaves when the three species of Cucurbitaceae will be submitted to adding of organic pig dejecta. Likewise, it will be necessary to avoid measurement of diameter of stem when the 2

\section{REFERENCES}

Bembé A.P., Mabanza J., Mingui J.M. et Mialoundama F., 2010. Etude de quelques caractères végétatifs chez trois espèces de Cucurbitaceae locales cultivées au Congo Brazzaville: Largenaria siceraria, Citrullus lanatus et Cucurbita moschata; Ann. de l'Université M. Ngouabi 11 (4): 16-21.

Bertucci M.B., Suchoff D.H., Jennings K.M., Monks D.W., Gunter C.C., Schultheis J.R., and Louws F.J., 2018. Comparison of root system
The adding of organic pig dejecta allowed better growth of diameter at collar, length of stem and cumulative count of flowers. Stems and flowers for their growth and development could directly use assimilated nutrients. Bembé et al., (2010) and Salifou et al., (2015) working without dejecta, shown that Lagenaria sp. recorded low values of length of stem than us. Indeed, organic farm dejectas bring major nutrients such as $\mathrm{N}, \mathrm{P}, \mathrm{K}, \mathrm{Ca}$ and $\mathrm{Mg}$ the minor ones such as $\mathrm{Cu}, \mathrm{Zn}, \mathrm{Mn}, \mathrm{Fe}, \mathrm{B}$ and Mo requested for growth of cultivated plants (Tran Sen et al., 2007). Thus, 3 kilogrammes of organic pig dejecta should be brought in seed pocket before the sowing. They are necessary to improve the growth of stem and cumulative count of flowers Lagenaria siceraria expressed good growth of diameter at collar as well as that of length of stem while Cucurbita pepo shown good yielding of flowers. The genes from species Lagenaria siceraria could be activated more easily for growth whereas those from Cucurbita pepo in flowers and fruits yielding. Bembé et al., (2010) reported that Largenaria siceraria grown more than Cucurbita moschata. Zoro Bi et al., (2003) shown that Largenaria siceraria yielded more flowers than Cucurbita moschata.

Status and 3 Species will be associated to gain the time. The adding of organic pig dejecta allowed better growth of diameter at collar, length of stem and cumulative count of flowers. Thus, 3 kilogrammes of organic pig dejecta should be brought in seed pocket before the sowing. They are necessary to improve the growth of stem and cumulative count of flowers. Lagenaria siceraria expressed good growth of diameter at collar as well as that of length of stem while Cucurbita pepo shown good yielding of flowers. Therefore, for more growth of stem, Largenaria siceraria should be used whereas for the yielding of higher number of flowers and fruit, Cucurbita pepo should be recommended.

morphology of cucurbit rootstocks for use in water melon grafting, 28 (5): 629-636.

Dje Bi I. R., Koffi K.K., Baudoin J.P. et Zoro Bi I.A., 2011. Effet de la saison de culture et de la densité des plants sur les adventices et la production de la cucurbite oléagineuse Citrullus lanatus (Thunberg) Matsum. \& Nakai (Cucurbitaceae), Sciences \& Nature 8 (1): 85 - 93.

Issali A.E., Traoré A., Amoncho A., Mpika J., Kouassi A., Konan J.L., Andi Kohi J.N. and Sangare A., 2011. Staminodes and petals interaction in co- 
culture and growth of somatic embryo-derived plantlets of Theobroma cacao L., in the greenhouse. Journal of Applied Bioscience (from India). 37 (1): 1-8.

Salifou A., Alidou C., Tchobo F.P. et Soumanou M., 2015. Connaissance endogènes et importance des courges (Cucurbitaceae) pour les populations autochtones productrices des graines au Bénin, J. of App. Biosc. 92: 86398650.

Tran SenT., Côté D. et N'Dayegamiye A., 2007. Effet des apports prolongés du fumier de et de lisier sur l'évolution des teneurs du sol en éléments nutritifs majeurs et mineurs, Bio97 Consultation sur le développement durable de la population porcine au Québec 62 (11): 21-30.

Zoro Bi I.A., Koffi K.K. et Djé Y., 2003. Caractérisation botanique et agronomique de trois espèces de cucurbite consommées en sauce en Afrique de l'Ouest: Citrullus sp, Cucumeropsis mannii Naudin et Lagenaria siceraria (Molina) Standl, Biotechnol. Agron. Soc. Environ. 7 (3-4) : 189199. 